\title{
The Impact of Bank Tax on Lending Margin
}

\author{
Paulius Ceponis, Marius Kuslys, Tadas Sarapovas
}

\author{
ISM University of Management and Economics \\ Ausros Vartu st. 7A, Vilnius, Lithuania \\ E-mail.018594@stud.ism.lt; markus@ism.lt; tadsar@ism.lt
}

cross $^{\text {ref }}$ http://dx.doi.org/10.5755/j01.ee.32.3.27208

\begin{abstract}
In February 2016, Poland implemented a bank tax paid by monetary financial institutions based on the assets of their balance sheets. Two years later, the same tax was proposed in Lithuania. Critics of the tax claimed that the tax burden in Poland shifted to customers by increasing the lending margin, and were this tax to be implemented in Lithuania, negative economic consequences would be likely. The aim of this paper is to estimate the potential impact of the bank tax on the lending margin in Lithuania by evaluating the case of Poland. Currently, research studies do not provide a definitive answer about the effects of bank taxation, mainly because various types of bank tax exist. Further research of the bank tax implemented in Poland could provide more information about the consequences of the bank tax applied to the assets of financial institutions. Also, a previous investigation of Poland's bank tax was limited by a short time series. Currently, a more accurate analysis could be done by using data over a longer period of time. Following previous research, differencein-differences estimation is used to evaluate the impact of the policy change and uses data from the period 2012 to 2020. The results of the analysis are significant and show that the bank tax had a positive impact on lending margins in Poland by an average value of 0.39. The descriptive analysis of the Herfindahl index shows that the banking sector of Lithuania is highly concentrated, implying that the tax burden would be shifted to bank customers by increased lending margins. In this way, the banking sector in Poland managed to avoid paying the levy by shifting the burden onto consumers. The same outcome is to be expected in Lithuania. The findings of the paper suggest that Lithuania should consider alternative ways of taxation since increased lending rates could have a negative effect on the overall economy of the country.
\end{abstract}

Keywords: Bank Tax; Banking Sector; Lending Margin; Difference-In-Differences Estimation; Herfindahl Index.

\section{Introduction}

In 2018, a Lithuanian political party proposed a bank tax, based on a similar bank tax introduced in Poland two years earlier. The concept of a bank tax arose after the global financial crisis, with the aim of making the financial sector contribute to the well-being of the economy.

Several countries have introduced a bank tax, but the Polish case is the closest to the one proposed in Lithuania. Several research papers have suggested that, in general, bank taxes have a positive and significant impact on lending margins, but in Poland's case, the result was insignificant. A previous analysis of Poland's bank tax was performed shortly after its introduction. A longer time series is now possible, allowing for a more reliable analysis with the potential to producing recommendations for Lithuanian policymakers.

The problem of this research is: what impact has the implementation of Poland's bank tax had on the lending margin? The aim of the paper is to estimate the impact of the bank tax on the lending margin in Poland and evaluate the possible effects of such a tax were it to be introduced in Lithuania.

The research will be conducted by using the difference-in-differences method. This is a standard method to evaluate the results of policy changes.

\section{History of Bank Taxes}

The financial crisis of 2008 was a huge shock for the global economy. In response, the G20, the international forum uniting the world's strongest economies, met at the Pittsburgh Summit on September 24-25, 2009. In the G20 Leaders Statement, in a chapter called "Strengthening the International Financial Regulatory System", they asked the International Monetary Fund to prepare a report "with regard to the range of options countries have adopted or are considering as to how the financial sector could make a fair and substantial contribution towards paying for any burdens associated with government interventions to repair the banking system" (G20, 2009).

The IMF proposed two types of taxes on the financial sector. The first was called a "Financial Stability Contribution" (FSC). Essentially, this is a levy on the fiscal cost for any government support to the banking sector. It proposed the creation of an emergency fund that could be used for bailing out banks or by paying guarantees for them in the event of a crisis. The FSC would be paid by all financial institutions at a flat rate, which would be adjusted according to the type of financial institution.

The second proposed type was called a "Financial Activities Tax" (FAT). It is a simpler way of taxing financial institutions based on their profits and remuneration. In the report (IMF, 2010) it is suggested that the base of the tax should be the financial company's balance sheet, preferably its liabilities. To minimise harmful effects for the companies - such as discouraging 
capital accumulation or double taxation - equity and some other liabilities would be exempt from taxation. The levy could be used to discourage such activities as wholesale funding, short-term debt, or foreign funding, so one possibility is to have it applied on selected liabilities. The report also mentions that insured liabilities could be excluded from the tax base to avoid double taxation, and some off-balance sheet items could also be included in the tax base.

\section{Bank Tax in Europe}

Since a significant amount of time since the IMF's proposal has passed, the current situation of the bank tax in the EU can be evaluated. According to Kogler (2019), a number of European countries have implemented the tax in different ways since 2010. Countries such as Germany, the UK and the Netherlands implemented taxes that are close to the initial proposal, while other countries such as Hungary and France have introduced a different version of the tax. Kogler (2019) also claims that, in general, countries followed the IMF model by having liabilities as a tax base and excluded equity and insured deposits, while countries such as Hungary are something of an exception and have assets as a tax base. The main differences of the taxes throughout Europe are whether they are flat or progressive, and whether they differ in terms of short and long-term liabilities taxation. Moreover, the tax rates also vary across countries.

Currently, 14 OECD countries in Europe have imposed bank taxes (Asen, 2019). Romania is not in the OECD yet nevertheless implemented a bank tax in 2019 (EY, 2019). These taxes have significant differences, however, and so for comparative purposes, since Lithuania's proposal is a tax on assets, only countries that have selected assets as their tax base are going to be evaluated: Hungary, Poland, Slovenia and Romania.

Although Hungary and Slovenia both tax assets, their tax base differs from Poland's, primarily due to certain exemptions. Accordingly, Hungary and Slovenia will not be evaluated in this paper. Romania implemented the tax only recently (2019) and have already implemented changes in the tax base, thus presenting research limitations that are better to be avoided. This leaves Poland, which will be sole point of comparison.

\section{Bank Tax in Poland}

Poland's bank tax came into force on 1 February 2016 (EY, 2016). It is payable by financial institutions, including domestic banks, branches of foreign banks, consumer loan lending institutions and insurance companies, and branches of foreign insurance companies.

The tax is calculated by using the balance sheet of a financial institution. For banks, cooperative saving institutions and credit funds, the tax is payable when their assets exceed 4 billion Polish zlotych (PLN). For insurance companies, the threshold is 2 billion PLN, and for consumer loan lending institutions, the threshold is 200 million PLN.

The rate of the tax is $0.0366 \%$ per month and $0.44 \%$ per year. There are some exceptions that reduce the tax base, such as the value of equity and holdings of Polish Treasury bonds. The tax is calculated monthly.

Table 1 shows the revenue of the bank tax versus the total state revenue of Poland. The figures are only for 2016-2018 because the final results of 2019 are not confirmed yet. The revenues of the bank tax have been growing alongside the total state revenue of Poland, and equal around $1.2 \%$ of total state revenue.

Table 1

Bank Tax Revenue and Total State Revenue of Poland (PLN, Million)

\begin{tabular}{lccc}
\hline \multicolumn{1}{c}{ Year } & $\mathbf{2 0 1 6}$ & $\mathbf{2 0 1 7}$ & $\mathbf{2 0 1 8}$ \\
\hline State revenue & $314,683.60$ & $350,414.70$ & $380,048.10$ \\
Bank tax revenue & $3,506.81$ & $4,341.22$ & $4,507.39$ \\
\% of revenue & $1.11 \%$ & $1.24 \%$ & $1.19 \%$ \\
Effective tax rate & $0.17 \%$ & $0.21 \%$ & $0.20 \%$ \\
\hline
\end{tabular}

Source: compiled by the authors by using data from Statistics Poland and Ministry of Finance of Poland

Due to the thresholds of the tax, the effective rate of bank tax is lower and was calculated by evaluating the tax revenues and the total assets of monetary financial institutions of Poland: in 2018 it was $0.2 \%$.

\section{Literature Review}

An analysis of the current implementation of the bank tax showed that most countries have liabilities as a tax base, in line with the proposal of the International Monetary Fund after the financial crisis of 2008. However, political decisions and opinions regarding the bank tax have differed throughout Europe, primarily due to uncertainty about what the potential impacts of a bank tax could be on economies. The current literature does not provide a clear answer about the impact of the bank tax.

Economic theory states that the tax incidence burden can be unequally distributed between buyers and sellers. The same logic can be applied in the analysis of the bank tax. Kogler (2019) applied the Monti-Klein model to theoretically investigate how bank levies affect lending rates, deposit rates, and net interest margins. Two scenarios were analysed. In the first case, when "banks are loan-rich and deposit-poor" (Kogler, 2019, p. 684), banks will tend to increase lending rates. This was explained by optimal banks' behaviour. Bank levies increase borrowing costs, leading banks to reduce the volume of loans, which in turn leads to higher lending rates. Part of the tax burden, then, will be borne by borrowers.

Next, Kogler (2019) analyses when "banks are loanpoor and deposit-rich" (Kogler, 2019, p. 688). The outcome is very similar, although in this case, a bank levy will lead to lower deposit rates, and the tax burden will be borne by depositors.

The main conclusion suggested by the optimal behaviour of banks is that "a bank levy increases the net interest margin" (Kogler, 2019, p. 686), thereby suggesting that banks shift the tax burden to borrowers or depositors and that this leads to a higher lending margin.

From a theoretical perspective, a bank tax can be understood as a Pigovian tax. According to Perotti \& Suarez (2011), growing credit can create negative externalities related to systematic risk. The authors claim 
that the implementation of a bank tax on short-term funding could allow for internalizing these externalities. That said, it is important to note that bank taxes, once implemented, are not necessarily optimal.

As previously mentioned, the bank tax in Poland will be used as the basis of this analysis. The outcomes of the bank tax in Poland have been analysed in several research papers. Jarno and Kolodziejczyk (2018) evaluate the effects of the bank tax two years after its implementation, using the difference-in-differences method. Czechia was chosen as a control group for the estimation due to their similar level of economic development and because they have not yet implemented a bank tax. Jarno and Kolodziejczyk estimated the impact on the return on assets of the entire banking sector, the total value of loans granted by the banking sector, the total value of the assets of the banking sector, and the total number of employees in the banking sector (employment was considered as a cost of operations). Their analysis covers the period from January 2014 to December 2017.

The authors found a positive effect on the banking sector's employment and negative effects on ROA, the value of assets, and the value of loans of the Polish banking sector. Overall, the results were not statistically significant. Moreover, the results were contradictory: the authors assumed that employment would decrease the operating costs in an adverse environment. The researchers explained the likely reason why the results were not statistically significant: because the time series was too short - the study was conducted just two years after the implementation of the bank tax. A second reason could be that Czechia is not an ideal control group, although it did appear to be the best option after evaluating its macroeconomic and banking sectors. Nevertheless, Jarno and Kolodziejczyk argued that the difference-indifferences method is the most suitable since it was successful in other similar studies.

The possible effects of bank tax were analysed by Dec and Masiukiewicz (2011), well before the bank tax had been implemented in Poland. The authors' assessment was that, in general, a bank tax in Poland would have a negative impact. The two main reasons for this were: first, the likelihood that the new cost for the banks would be shifted to clients; and second, banks were already paying mandatory contributions towards the Bank Guarantee Fund. Based on these two reasons, the authors did not see enough of a justification implement the tax.

They have also provided a list of negative consequences which are likely if the tax is implemented. These include the risk of double taxation on the international level, two similar domestic tax duties (Bank Guarantee Fund and bank tax), the risk of banks leaving the country, possible deterioration of competition conditions due to tax asymmetry, unrelated levels of tax, and risk and the likeliness of the increase of the credit price as the costs imposed by the tax could be shifted to the clients.

In another paper by Dec and Masiukiewicz (2012), they continued discussing the possible implementation of the bank tax. They added that the banking sector of Poland was already one of the most heavily taxed in the country, and that the new tax could have a very negative impact on the activities of Polish banks. Even so, liabilities were discussed as a possible tax base for the new tax. The authors concluded that special taxes, such as the bank tax, have many drawbacks, but are a reasonable option for ensuring a proper allocation of funds needed for the possible restructuration of banks.

Capelle-Blancard \& Havrylchyk (2017) studied the bank levy by analysing the case of Hungary, where a bank tax was introduced in 2010. They used the Klein-Monti model as a benchmark, and according to the premises of the model, the incidence of the bank tax on loans had a negative correlation with the demand for loans and a positive correlation with the market power of the banks. Although Hungary is out of the scope of our paper primarily because of the differences between Poland's tax and Hungary's, Capelle-Blancard \& Havrylchyk (2017) found Hungary to be a perfect case for their purposes due to the different tax rates for large and small institutions. By using a difference-in-difference methodology they found that banks managed to significantly shift the burden of the bank tax onto customers by increasing their margins, but this conclusion is applicable only for outstanding loans due to a lower elasticity of their credit demand since there was no significant hike of interest rates for new loans. Compared to the loans of small banks, yearly net interest and the fee margin increased by $0.84 \%$. It is also worth mentioning that Hungary's retail banking sector is considered to have a poor level of competition (Havrylchyk, 2012).

Buch, Hilberg, and Tonzer (2016) discuss the impact of the German bank levy implemented in 2011. The bank tax of Germany differs from Poland's: the tax base is calculated by taking the total liabilities of the bank and deducting equity and retail deposits. The threshold for paying the tax is $300 €$ million of contribution-relevant liabilities. To analyse the impact of the tax, the researchers took the balance sheets, profit and loss statements, and other prudential indicators of German banks for the period of 2008-2011. They chose a difference-in-differences approach for their analysis.

The results showed that the threshold was set so high that $77 \%$ of German banks were exempt from the tax and revenues raised through the tax were lower than expected. They did not see any change of behaviour in terms of the provision of new loans, however, banks impacted by the tax increased their total volume of loans less than the banks which were not impacted. Moreover, they raised interest rates for new deposits more than the banks which were not subject to the tax. Banks' cost of wholesale funding also increased.

Kogler (2019) estimated the impact of the German bank tax on the interest income on loans as a share of average loans, interest expenses on customer deposits as a share of average deposits, and the net interest margin. Kogler (2019) used the Klein-Monti model as a benchmark, and used the fixed effects (OLS) estimator drawing on data from 2,987 banks from 23 European countries between the period 2007 and 2013. It should be mentioned that a majority of the 23 countries had a tax on liabilities, not on assets.

The results showed that a bank tax led to a higher lending rate and net interest margin, effectively meaning 
that banks passed the tax burden onto borrowers. For the taxed banks, interest income on loans increased, while interest expenses to deposits also increased, leading to an increase of the lending margin. Moreover, Kogler (2019) claims that bank competition and capitalization are the main factors which determine the extent to which the tax burden is shifted to borrowers. Supporting this is his finding that there is a higher lending rate in markets where the banking sector is highly concentrated than in those that are less concentrated.

In another paper by Haskamp (2016), the effects of the German bank levy from 2011 to 2014 are discussed. Haskamp's findings are in line with Kogler's (2019): banks that are subject to the bank levy tend to increase their loan rates. Moreover, Haskamp confirmed the findings of Buch et al. (2016) that the bank tax has a negative effect on the growth of a bank's loan volume.

Albertazzi and Gambacorta (2010) published an article in which they investigate how the activity of banks are affected by corporate income taxes. Although our article does not investigate the impact of the bank tax, it does helps to understand how changes in taxation may affect banks in general. Albertazzi and Gambacorta used aggregated data on the main components of profit-loss statements and on the interest rates applied on loans and deposits for ten industrialized countries (Austria, Belgium, France, Germany, Italy, The Netherlands, Portugal, Spain, United Kingdom, and the United States) throughout the period 1981-2003.

Albertazzi and Gambacorta (2010) concluded that taxing the profit of banks is equivalent to taxing the loans owned by the bank. An increase in the corporate income tax rate has led to an increase in the interest rates demanded on loans and a decrease in the lending volumes. They also found that there was no effect on the deposit market. Moreover, they noticed that banks have been able to shift at least $90 \%$ of their corporate income tax burden.

The possible macroeconomic effects of the three types of bank taxes (on profits, loans, and deposits) were analysed by Bosca, Domenech \& Ferri (2019). They found that the effects of different taxes are similar: banks reduce the volume of loans and increase interest rates on loans. This has negative effects on the overall economy. An increase in interest rates means that banks are able to shift the tax burden onto customers. A review of various empirical studies by Gawehn (2020) agrees with this finding: corporate income taxation has an impact on banks' pricing decisions, which leads to a higher tax burden on customers.

On the other hand, some types of bank taxes may have different effects on the banking system. For example, Boadway, Sato \& Tremblay (2020) indicate that real and financial cash-flow taxation has no effect on lending, if this tax ensures full loss compensation, even if the bank is insolvent. According to an analysis done by Celerier, Kick \& Ongena (2019), taxing bank leverage will push banks to more lending instead of investing in government securities.

In short, previous research studies have not provided a clear answer about the effects of bank taxation. The results vary depending on the type of tax, analysed variables, time period, etc. Studying the bank tax implemented in Poland will, then, provide more information about the effects of a specific bank tax when it is applied to the assets of financial institutions.

\section{The Determinants of Lending Margin}

The main aim of this paper is to estimate the impact of a bank tax on the lending margin. However, the lending margin is affected by other factors as well. This chapter will summarize the determinants of lending margin discovered in previous research.

Claeys and Vander Vennet (2008) investigated bank interest margins in Central and Eastern European countries (CEEC). They found that lending margins are not determined by bank market structure to a high extent, but the presence of foreign banks reduces lending margins effectively, irrespective of the fact that foreign banks have acquired large market shares in CEEC. The authors also explain that some countries can offer lower lending margins due to the higher operational efficiency of the banks, while a high capital adequacy level is also a factor that ensures stability and helps to keep lending margins low. Finally, the authors provide recommend that the dominance of state-owned banks in lending should be reduced because foreign banks create downward pressure on lending margins by improving the operational efficiency of the banking sector.

Horvath (2009) investigated the determinants of lending margins of the banks of Czechia for the period 2000 to 2006. The main findings were that more efficient banks exhibit lower lending margins and there is no empirical evidence that the banks which manage to offer lower lending margins compensate themselves with higher fees. Moreover, it was found that price stability contributes to lower margins and larger banks tend to charge lower lending margins. Higher capital adequacy also leads to lower interest margins.

Demirguc-Kunt and Huizinga (1998) analysed banking data from 80 countries over the period 1988 to 1995 . They found that countries with more competitive banking sectors have smaller lending margins, and in developing countries foreign banks have greater margins than the local banks, while in industrial countries it is the opposite. Macroeconomic factors such as inflation also explain some of the variation in interest margins since inflation is associated with higher realized interest margins. There is also evidence that the burden of corporate tax is fully passed onto bank customers in both poor and rich countries to a similar extent.

Agoraki and Kouretas (2019) studied what determined the net interest margins (lending margins) of CEEC during the transition period 1998 to 2016. They provide robust evidence that regulatory frameworks have played a crucial role in the development of the banking sector of CEEC during the transition period. Their results show that the entry of foreign banks has created downward pressure on lending margins by improving the operational efficiency of the banking sector. Finally, the effect of inflation (although it was weak) on lending margins was determined, and the effect of GDP was not significant.

Hanzlik and Teply (2019) examined a sample of annual data on 629 banks from EU member states over the period 2011 to 2016. One key finding was that higher 
market concentration, measured by the Herfindahl index, leads to higher net interest margins.

Dumicic and Rizdak (2013) investigated the determinants of net interest margins (NIM) of CEEC during the period 1999 to 2010 . They confirmed the findings of the other authors: that the increasing efficiency of the banking sector has driven the lending margins downward.

Summing up the literature review, the main findings are that banks are able to shift the burden of the bank tax, and the extent to which they shift it is determined by the concentration of the specific market (Capelle-Blancard \& Havrylchyk, 2017; Haskamp, 2016; Kogler, 2019). However, the analysed countries (Hungary, Germany) have a different form of bank tax than Poland's. The suggested bank tax in Lithuania is similar to the one introduced in Poland. Thus far, research studies analysing the bank tax in Poland have not provided statistically significant results (Jarno \& Kolodziejczyk, 2018), and this allows us to speculate about the potential effects of such a tax in Lithuania. Now that longer time series are available, a better analysis can be performed, and this will allow us to estimate the possible effects of a bank tax in Lithuania and similar economies.

Other factors that may have an impact on lending margins are inflation and the operational efficiency of the banks. It has generally been observed that the entry of foreign banks creates pressure to increase the efficiency of a country's banking sector and drives lending margins downwards.

Given the findings of this previous research, the hypothesis is:

Hypothesis: The implementation of the bank tax had a positive impact on lending margins in Poland.

Nearly all evaluations of the bank tax have been performed by using difference-in-differences estimation (Capelle-Blancard \& Havrvylchyk, 2017; Buch et al., 2016; Jarno \& Kolodziejczyk, 2018), and this method will also be used for testing the research hypothesis.

\section{Research Methodology}

According to Woolridge (2012), the difference-indifferences methodology is useful when the data is observed from a natural experiment, which occurs when something has been changed in the operating environment of the subject of the research. A good example of the change could be the implementation of the new tax.

A natural experiment always has two groups - one which was affected by the policy change and one which was not. As Poland has implemented the bank tax, it will serve as a treatment group, and Czechia will be a control group since it was not affected by the policy change that occurred in Poland.

To evaluate the effect of the change and to perform difference-in-differences estimation, two equal groups of data are needed - one before the policy change and one after it.

The general equation of difference-in-differences estimation is provided below (Woolridge, 2012, p. 457):

$\mathrm{y}=\beta_{0}+\delta_{0} d 2+\beta_{1} d T+\delta_{1} d 2 \cdot d T+$ other factors

In the equation, $\mathrm{d} 2$ stands for the dummy variable, which is 1 for the period after the policy change and 0 before the policy change. $\mathrm{dT}$ is a dummy variable that has a value of 1 when the observation is related to the treatment group. $\delta 1$ is the most important coefficient of the equation, called the difference-in-differences estimator, or average treatment effect. The aim of the coefficient $\delta_{1}$ is to demonstrate what impact the policy change had on the treatment country. As the product of the variables $d 2$ and $d T$ is going to be 1 only in these cases, when the observations are for the treatment country after the policy change and 0 otherwise, the coefficient will show the actual effect of the policy change.

\section{Empirical Research}

The part is dedicated to testing the hypothesis that the implementation of the bank tax had a positive impact on bank lending margin in Poland.

First, a difference-in-differences estimation is performed, in line with much of the research discussed in the literature review.

Second, the results of the analysis are evaluated and interpreted, followed by a descriptive analysis of the dynamics of the Herfindahl index, which was not included in the regression but might nevertheless be useful for estimating the possible impact of the tax on the Lithuanian economy.

\section{Sample Data}

As difference-in-differences estimation requires, the sample data contains two time periods of equal length one before the implementation of the bank tax in Poland and one after the tax has come into force. Since the monthly data for bank lending margins at the time of performing this research is available only until February 2020 and the tax was implemented in February 2016, the period after the implementation consists of 49 months. Applying the same amount of time before the tax came into force in Poland, the data used starts in January 2012 and ends in January 2016.

Following Jarno \& Kolodziejczyk (2018), Czechia is used as the control group for difference-in-differences estimation. The main reasons for this selection are the geographical proximity and relatively similar level of economic development, plus, Czechia has not implemented any kind of bank tax.

Due to the reasons described in the previous paragraph, the respective data of Czechia for the same period of time is used; the values of bank lending margins in this country is used as a control group for the differencein-differences estimation.

The data set is organized as panel data, where there are two cross-sectional units (Poland and Czechia), and 98 time periods (from January 2012 to February 2020). In total, 196 observations are used in the analysis.

The dataset was constructed by the authors of the paper by using the data from ECB Statistical Data Warehouse and OECD Data. The data for the majority of the variables are taken from ECB as only the data for Composite leading indicator (CLI) is from the OECD database. 
Paulius Ceponis, Marius Kuslys, Tadas Sarapovas. The Impact of Bank Tax on Lending Margin

\section{Variables}

Dependent variable. The dependent variable for the regression analysis is lending margins of monetary financial institutions (MFI) on new loans to households and non-financial corporations (denoted as Lendingmargin). The dataset contains observations both for Poland and Czechia. The data for this variable is taken from the Statistical Data Warehouse of the European Central Bank. The lending margins of MFIs are calculated as the difference between the lending interest rates and a weighted average rate on deposits.

Independent variables. The independent variables of the regression are constructed following the methodology of difference-in-differences estimation described by Woolridge (2012). It requires the regression to contain variables that distinguish control and treatment groups and the periods of time before and after the policy was implemented. These are the standard variables of difference-in-differences estimation, used in many similar empirical research papers (for example Jarno \& Kolodziejczyk, 2018, etc.).

The first independent variable, denoted as $d T$, shows if the country is considered as a control group or as a treatment group. In this case, as Poland is the treatment group, $d T$ is going to be 1 for Poland and 0 for Czechia. This variable captures the systematic differences between Poland and Czechia (Woolridge, 2012). Despite the similarities between Poland and Czechia, described beforehand, some differences between these countries also exist and these differences might affect lending margins as well. The variable $d T$ shows the average difference in lending margin between Poland and Czechia, caused by systematic differences. This effect needs to be captured in order to distinguish the effect of systematic differences and the effect of the introduced bank tax.

The second independent variable, denoted as $d 2$, indicates if the observation was made before or after the policy, in this case, when the bank tax in Poland was implemented. The value for $d 2$ is 1 for observations starting from February 2016 and 0 otherwise. This variable estimates the average difference in lending margin before and after February 2016. Some other systematic changes, not related to the introduction of the bank tax, might occur, thus this variable captures these effects.

The third independent variable, denoted as $d 2 d T$, is the product of the multiplication of variables $d 2$ and $d T$. The aim of it is to distinguish the observations of the lending margins of Poland after the policy was implemented; in other words, to be able to evaluate which observations are from the treatment group after the specific policy change. The specification of this variable indicates that it captures the effect of the introduction of the bank tax. So, the estimate of the variable $d 2 d T$ measures the average effect of the bank tax on the lending margin (Woolridge, 2012).

Control variables. Following the literature review, several control variables are introduced into the regression analysis. They represent the factors that might have an impact on lending margins, including macroeconomic factors and the volumes of loans of the monetary financial institutions.

The first control variable for the analysis is Inflation, which represents a portion of the economic factors of the country (Demirguc-Kunt \& Huizinga, 1998). It was used by Agoraki and Kouretas (2019), for example, as a potential determinant of net interest margins and was found to be a significant factor. According to Agoraki \& Kouretas (2019), higher inflation is related to higher loan rates and higher lending margins. Based on this explanation, the hypothesis regarding this variable is that inflation has a positive effect on lending margins.

The second control variable is the Composite leading indicator. This indicator represents the situation of the overall economy and the data for it is provided by the OECD. The variable is intended to provide information about the business cycles the country is currently in and, according to the OECD, it shows short-term economic movements in qualitative terms. Due to that, the percentage change of monthly CLI is used for the research and the transformed variable is denoted as CLIPercent. Agoraki \& Kouretas (2019) used real GDP growth to capture the overall economic environment. Although they found no significant effect regarding the connection between GDP growth and net interest margins, CLI growth is a bit different and is used as a proxy for the economic situation of the countries. A better economic environment is associated with a lower risk of default, and it should increase lending and net interest earnings (Agoraki \& Kouretas, 2019; Claeys \& Vander Vennet, 2008; etc.). So, the hypothesis for this variable is that a growing economy causes an increasing demand for loans, therefore, the banks could charge higher margins, so the positive change of CLI leads to a positive change of lending margins.

The third control variable is the volumes of loans visa-vis domestic non-MFI excluding general government reported by monetary financial institutions and excluding ESCB (The European System of Central Banks). Although other researchers (Capelle-Blancard \& Havrylchyk, 2017) have used total assets as a tool to differentiate different types of banks, which in this case could be the banks of Poland and Czechia, loans make up a major portion of the balance sheets of the banks and are more closely linked with the main subject of the research, which is the lending margin. Since using both total assets and domestic loans is not possible as these variables are likely to be correlated, domestic loans have been chosen as the control variable. According to one of the premises of the Klein-Monti model, which was used as a benchmark for most of the research about the incidence of the bank tax, the incidence of the tax is negatively correlated with the elasticity of demand for loans. The hypothesis for this variable, according to the Klein-Monti model, is that the increase of the volume of loans will have a positive impact on lending margins as the increasing volumes would stand for the increasing demand. In order to see the dynamics of domestic loans, the percentage change of the volume of loans is used, denoted as LoansPercent.

\section{Summary Statistics and Correlation Matrix}

Table 2 includes summary statistics for each variable. During the period January 2012 to February 2020, the dependent variable, which is the lending margin in Poland and Czechia, varied from the highest point of $0.15 \%$ to $2.77 \%$. 
The mean and median values of the variables are not significantly different, thus there is no indication of significant outliers or asymmetries. The minimum and maximum values of variables suggest the same implication. The coefficient of variation (C.V.) indicates that CLIPercent has the highest relative spread. The value of skewness implies that Lendingmargin and LoansPercent are slightly negatively skewed while other variables are almost symmetrical. Excess kurtosis shows that Lendingmargin and Inflation have platykurtic distribution, while LoansPercent and CLIPercent have leptokurtic distribution, which can be explained by high relative variation.

Table 2

Summary Statistics of the Variables

\begin{tabular}{lcccc}
\hline \multicolumn{1}{c}{ Variable } & Mean & Median & Minimum & Maximum \\
\hline Lendingmargin & 1,82 & 1,95 & 0,15 & 2,77 \\
Inflation & 1,41 & 1,40 & $-1,30$ & 4,30 \\
LoansPercent & 0,43 & 0,44 & $-4,59$ & 3,46 \\
CLIPercent & $-0,02$ & $-0,01$ & $-0,52$ & 0,46 \\
\hline Variable & Std. Dev. & $\mathrm{C} . \mathrm{V}$. & Skewness & Ex. kurtosis \\
\hline Lendingmargin & 0,56 & 0,31 & $-0,57$ & $-0,54$ \\
Inflation & 1,35 & 0,95 & 0,29 & $-0,73$ \\
LoansPercent & 1,15 & 2,69 & $-0,55$ & 1,92 \\
CLIPercent & 0,13 & 8,70 & 0,09 & 3,34 \\
\hline
\end{tabular}

Source: Authors' estimates

The frequency distribution table of variables $d T, d 2$, and $d T d 2$ is provided in Table 3 . Both variables $d T$ and $d 2$ are distributed completely equally, which confirms that the dataset is constructed properly in terms of having observations over the same amount of time before and after the implementation of the bank tax. As exactly one quarter of the values of the dummy variable $d T d 2$ is 1 , it also confirms the validity of the data, since only $25 \%$ of observations were obtained in Poland after the policy change.

Table 3

Frequency Distribution of Independent Variables of the Model

\begin{tabular}{ccc}
\hline Variable & 0 & 1 \\
\hline$d T$ & $98(50 \%)$ & $98(50 \%)$ \\
$d 2$ & $98(50 \%)$ & $98(50 \%)$ \\
$d T d 2$ & $147(75 \%)$ & $49(25 \%)$ \\
\hline
\end{tabular}

Source: Authors' estimates

The correlation matrix from Table 4 is a tool that helps to foresee the possible problem of multicollinearity, in other words, linear relationship between explanatory variables. With a confidence interval of $95 \%$ and a total number of 196 observations, the critical value for the twotailed test is 0.14. In all cases, the problem of multicollinearity is not likely because correlations between independent variables are weak or moderate.
Correlation Matrix

\begin{tabular}{ccccc}
\hline Lendingmargin & Inflation & LoansPercent & CLIPercent & \\
\hline 1,00 & $-0,04$ & $-0,12$ & 0,17 & Lendingmargin \\
& $\mathrm{p}=0,585$ & $\mathrm{p}=0,082^{*}$ & $\mathrm{p}=0,016^{* *}$ & \\
\hline \multirow{4}{*}{1,00} & 0,04 & $-0,43$ & Inflation \\
& $\mathrm{p}=0,562$ & $\mathrm{p}<0,001^{* * *}$ & \\
\hline & 1,00 & $-0,11$ & LoansPercent \\
& & $\mathrm{p}=0,140$ & \\
\hline & & 1,00 & CLIPercent \\
\hline
\end{tabular}

Source: Authors' estimates

Note: $* * *$ indicates significance at $1 \%$ level, $* *$ indicates significance at $5 \%$ level, $*$ indicates significance at $10 \%$ level

\section{Specification of the Model}

Following the specifics of the differences-indifferences estimator, the model for the regression is specified below:

Lendingmargin $=\beta_{0}+\beta_{1} d T+\beta_{2} d 2+\beta_{3} d T d 2+$ $\beta_{4}$ Inflation $+\beta_{5}$ CLIPercent $+\beta_{6}$ LoansPercent $+\varepsilon$

$\beta_{0}$ stands for constant, $\beta_{1}, \beta_{2}$, and $\beta_{3}$ stand for the coefficients for variables created in order to perform the analysis of the selected method. $\beta_{3}$ is the most important coefficient of the regression analysis: it is the differencein-differences estimator, which shows the impact of the policy change for the treatment group. Coefficients $\beta_{4}, \beta_{5}$, and $\beta_{6}$ show the coefficients for the control variables and $\varepsilon$ stands for the error term.

\section{Results and Interpretation of the Model}

Before the interpretation of the results of the regression analysis, it is necessary to perform certain econometric tests to ensure that the constructed model is valid. After constructing the first version of the model and performing White's test for heteroscedasticity, it showed that it was a problem for this model $(\mathrm{p}=0,006)$. In order to ensure the validity of $\mathrm{p}$ values, robust standard errors will be used.

Testing for multicollinearity by using Variance Inflation Factors (VIF) did not show any problems since all the values vary between 1 and 3 , and only values higher than 10 indicate a multicollinearity problem.

Regarding autocorrelation, that is the second problem for this model. The Durbin-Watson test showed a value of only 1.43 , whereas the target value is around 2 . An attempt was made to improve the statistic by performing a logarithmical transformation of the dependent variable Lendingmargin and to transform it into percentage change. It helped to improve the statistics to 1.56 and 2.34, respectively. However, it caused a significant decrease of adjusted R-squared of the model and has not solved the autocorrelation problem to a large extent. Even more importantly, since the aim of the research is to estimate the impact on the values of lending margins, not on their percentage change, the interpretation of the results of the model would become complicated if the dependent variable is transformed. Due to these reasons, the original form of Lendingmargin has been kept in the model. 
The test for normality of residuals has shown that the residuals of the model are not distributed normally $(\mathrm{p}<0,001)$. Nevertheless, the histogram of the distribution of residuals visually looks similar to a normal distribution, so this limitation will not have a significant impact on the results of the model.

The results of the regression analysis are provided in Table 5, and it shows that all of the variables that were included in the model have an impact on the dependent variable Lendingmargin and they are all found to be statistically significant. As the p-values of the variables $d T$, $d 2, d T d 2$, Inflation, and CLIPercent are below 0.01, they are significant at a confidence interval of $99 \%$, whereas variable LoansPercent is significant at a $95 \%$ confidence interval. The R-squared of the model (Table 5), which shows the portion of the variance in the dependent variable that is explained by the independent variables, is 0.71 .

Table 5

Results of the Regression Analysis

\begin{tabular}{lccc}
\hline & Coefficient & p-value & \\
\hline const & 1,38 & $<0,001$ & $* * *$ \\
$d T$ & 0,72 & $<0,001$ & $* * *$ \\
$d 2$ & $-0,21$ & $<0,001$ & $* * *$ \\
$d T d 2$ & 0,39 & $<0,001$ & $* * *$ \\
Inflation & 0,09 & 0,002 & $* * *$ \\
CLIPercent & 0,76 & $<0,001$ & $* * *$ \\
LoansPercent & $-0,05$ & 0,048 & $* *$ \\
\hline R-squared & 0,71 & & \\
Adjusted R-squared & 0,71 & & \\
F(6, 187) & 78,04 & $<0,001$ & $* * *$ \\
\hline
\end{tabular}

Source: Authors' estimates

Note: *** indicates significance at $1 \%$ level, ** indicates significance at $5 \%$ level.

Interpreting the results, the coefficient of 0.72 of the variable $d T$ shows that lending margins on new loans have been higher in Poland than in Czechia, and the coefficient 0.21 of the variable $d 2$ indicates that lending margins were overall lower in both countries after the bank tax was implemented in Poland, February 2016. Both these observations align with the findings obtained in the situation analysis.

Regarding the control variables, both Inflation and CLIPercent show a positive impact on lending margins as expected, although the estimated impact of inflation is quite small with a coefficient of 0.09 .

One interesting finding is that the coefficient of the variable LoansPercent is negative, while the hypothesis was the opposite. The coefficient of -0.05 is rather low, and the mean percentage change of volume of loans used in this research is 0.43 , which indicates that the variations in this variable had an average impact on lending margins of only $0.02 \%$. As it is not a significant number, the causes of the negative coefficient of LoansPercent are not going to be investigated in detail, but the assumption would be that the increasing demand for loans could have caused an increase in deposit rates, which is one of the components of the calculation of lending margins, and in that way an increase in the volume of loans could have impacted the margins negatively.
The difference-in-differences estimator $d T d 2$, which is considered to be the most important variable of this analysis, shows the impact of the bank tax for the treatment group after the implementation of the policy. It has an estimated coefficient of 0.39 , which is significant at a confidence level of $99 \%$. That indicates that there is strong evidence that the tax had an actual positive impact on the lending margins of new loans and the burden of the tax was put onto individuals and non-financial corporations. The Hypothesis, then, cannot be rejected.

\section{Possible Implications of the Bank Tax to Lithuania}

The literature review suggested that a higher market concentration of a country's banking sector, which is usually demonstrated by the Herfindahl index, leads to higher lending margins and a greater portion of the tax burden is shifted to customers. Since the period after the bank tax was implemented in Poland is rather short, in order to be as accurate as possible with the estimations of the impact of the tax itself, the time series up until February 2020 was taken into consideration. As the latest data for the Herfindahl index is not available yet and it is not provided monthly, the decision to not include it in the regression analysis was taken. In order to have an extra tool to estimate the extent to which the same kind of tax would affect Lithuania, the descriptive analysis of the Herfindahl indexes of both Poland and Lithuania is included.

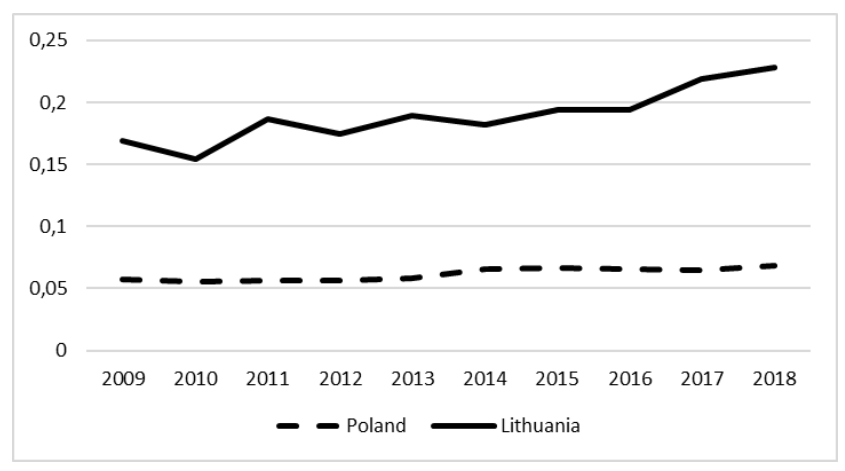

Figure 1. Herfindahl index in Poland and Lithuania. Source: $E C B$

The Herfindahl index in Figure 1 is calculated by taking the total assets of credit institutions (CIs) into consideration. It clearly shows that the banking sector of Lithuania is significantly more concentrated than the banking sector of Poland: in 2018 the HHI of Poland credit institutions was 0.06 , whereas the same index in Lithuania had a value of 0.23 . Taking this index into consideration, it is highly likely that Lithuanian credit institutions would indeed manage to shift the burden of the bank tax to their customers.

Assuming that Lithuania would select the same tax rate as in Poland, which is $0.0366 \%$ per month and $0.44 \%$ per year, and choose the same thresholds for paying the tax as in Poland, the possible tax revenue from the bank tax can be roughly estimated by taking the effective tax rate of Poland, which was $0.2 \%$ and the total assets of the Lithuanian banking sector as of December 2018 (for the sake of comparison), which were $30.07 €$ billion. That 
would result in approximately $60.6 €$ million of extra tax revenue, which would have been $0.7 \%$ of Lithuanian tax revenue in 2018, whereas in Poland it accounted for 1.19 $\%$ of state revenue. Following the results of the regression analysis, it is highly likely that the tax would increase the lending margins on new loans and that customers of the banks would effectively become the payers of the tax.

Even though the new tax would collect extra tax revenue, increased lending prices could have other negative effects on the overall economy and its growth. In general, higher lending interest rates will make lending less attractive, and the decrease in lending volumes would likely dampen consumption and investments. As a result, the growth of the economy would be impacted negatively. The findings of this paper suggest that the government of Lithuania should not implement the bank tax and look for alternative ways of taxation, for the simple reason that the banks would likely not pay the tax themselves but would rather shift the burden to their customers.

\section{Limitations of the Research}

As described in the section that detailed the tests of the model, a low value of the Durbin-Watson test, which is a sign of possible autocorrelation, is one of the limitations of the model. It was determined that it would be possible to increase the statistic by transforming the variables, especially the dependent variable, but that would be harmful to the entire logic of the model. Since it was constructed to estimate the impact of the bank tax on lending margins, the interpretation of the transformed dependent variable Lendingmargin would become more complicated, and due to these reasons, the transformations have not been performed.

It should also be mentioned that robust standard errors were used in order to deal with the heteroscedasticity problem. Nevertheless, the p-values for the majority of the variables are extremely low, so it is unlikely that the significance of the variables of the model are not valid. Finally, the distribution of the residuals is not normal, but as the histogram of it visually looks similar to a normal distribution, it does not significantly damage the quality of the model.

From an economic perspective, the Herfindahl index is a factor that would have been useful for the regression analysis, but since the most recent data is not yet available, only a descriptive overview of this index was included.

\section{Conclusions}

The international community began to consider implementing a new tax on banks after the financial crisis of 2008. In the IMF proposal, liabilities, excluding equity and insured deposits, were proposed as a tax base. As of
2019, 15 European countries have implemented this kind of taxation and the majority of them have liabilities as a tax base. Poland implemented a bank tax on assets in February 2016 with a nominal tax rate of $0.44 \%$, and due to various thresholds and exceptions, the effective tax rate in 2018 was $0.2 \%$ and the revenue of the bank tax has accounted for $1.19 \%$ of the state revenue of Poland in 2018 .

The literature review has shown that in the countries where the bank tax was implemented, banks have managed to shift the tax burden to their customers. The extent of it is largely dependent on the market concentration of each country's banking sector. One of the main factors of the lending margin is the operational efficiency of the banks. Entry of foreign banks tends to push the margin of the banking sector downward by applying pressure to improve the efficiency of the local market players. In terms of macroeconomic factors, inflation was proven to have a positive impact on lending margins. Difference-indifferences estimation was chosen as a research method for the econometric analysis. The main reason for choosing it is the fact that it is so commonly used in similar studies: this statistical technique is widely considered to be a proper tool for evaluating changes after a policy change.

Econometric research has shown that the implementation of the bank tax in Poland had a positive impact on lending margins by an average value of $0.39 \%$. Inflation is also a factor that has an impact on lending margins. Moreover, the analysis has shown that the overall status of the economy, described by the composite leading indicator, also has an impact on lending margins. The market concentration of the Lithuanian banking sector, as demonstrated by the Herfindahl index, is significantly higher than the HHI of the banking sector of Poland. In 2018, in Lithuania the index was 0.23 whereas in Poland it was only 0.06 . Taking the HHI factor into consideration, it is highly likely that the Lithuanian banking sector would manage to shift the tax burden to bank customers by increasing lending margins. If Lithuania chose to implement exactly the same tax as it is in Poland, the estimations show that Lithuania would collect around $60 €$ million per year based on the effective tax rate in Poland and the total assets of Lithuanian monetary financial institutions. That would account for $0.7 \%$ of the state revenue of Lithuania in 2018.

The results of this paper oppose the implementation of the Polish version of the bank tax in Lithuania or in other similar countries. Although it would be an additional source of tax revenue, the tax could have negative implications for the growth of the economy, and taxpayers are likely to be the customers of the banks, not the banks themselves. Therefore, it is advised to look for alternative ways of taxation.

\section{References}

Agoraki, M. E. K., \& Kouretas, G. P. (2019). The determinants of net interest margin during transition. Review of Quantitative Finance and Accounting, 53(4), 1005-1029. https://doi.org/10.1007/s11156-018-0773-y

Albertazzi, U., \& Gambacorta, L. (2010). Bank profitability and taxation. Journal of Banking \& Finance, 34(11), 28012810. https://doi.org/10.1016/j.jbankfin.2010.06.003 
Paulius Ceponis, Marius Kuslys, Tadas Sarapovas. The Impact of Bank Tax on Lending Margin

Asen, E. (2019, December 19). Bank Taxes in Europe. The Tax Foundation. Retrieved from https://taxfoundation.org /bank-taxes-in-europe-2019/

Boadway, R., Sato, M., \& Tremblay, J. F. (2020). Efficiency and the taxation of bank profits. International Tax and Public Finance, 1-21. https://doi.org/10.1007/s10797-020-09616-3

Bosca, J. E., Domenech, R., Ferri, J., \& Rubio-Ramirez, J. (2019). Macroeconomic Effects of Taxes on Banking (No. eee2019-09). FEDEA.

Buch, C. M., Hilberg, B., \& Tonzer, L. (2016). Taxing banks: An evaluation of the German bank levy. Journal of banking \& finance, 72, 52-66. https://doi.org/10.1016/j.jbankfin.2016.07.010

Capelle-Blancard, G., \& Havrylchyk, O. (2017). Incidence of bank levy and bank market power. Review of Finance, 21(3), 1023-1046. https://doi.org/10.1093/rof/rfx007

Celerier, C., Kick, T. K., \& Ongena, S. (2019). Taxing Bank Leverage: The Effects on Bank Portfolio Allocation. Available at SSRN 2829326.

Claeys, S., \& Vander Vennet, R. (2008). Determinants of bank interest margins in Central and Eastern Europe: A comparison with the West. Economic Systems, 32(2), 197-216. https://doi.org/10.1016/j.ecosys.2007.04.001

Dec, P., \& Masiukiewicz, P. (2011). Bank Tax in the European Union. Retrieved from http://www.ann.ugal.ro/ eco/Doc2011_2/DecMasiukiewicz.pdf

Demirguc-Kunt, A., \& Huizinga, H. (1999). Determinants of commercial bank interest margins and profitability: some international evidence. The World Bank Economic Review, 13(2), 379-408. https://doi.org/10.1093/wber/13.2.379

Dumicic, M., \& Rizdak, T. (2013). Determinants of banks' net interest margins in Central and Eastern Europe. Financial theory and practice, 37(1), 1-30. https://doi.org/10.3326/fintp.37.1.1

European Central Bank. (2020, March 19). ESRB Risk Dashboard Publication. 3.5/3.6 Lending margins of MFIs. Retrieved from http://sdw.ecb.europa.eu/reports.do?node=1000003308

European Central Bank. (2020). Statistical Data Warehouse. Retrieved from https://sdw.ecb.europa.eu/

EY. (2019, January 18). Global Tax Alert. Romania publishes Government Emergency Ordinance introducing new tax measures for 2019. Retrieved from https://www.ey.com/Publication/vwLUAssets/Romania_publishes_ Government_Emergency_Ordinance_introducing_new_tax_measures_for_2019/\$FILE/2019G_012859-

18Gbl_Romania\%20introducing\%20new\%20tax\%20measures\%20for\%202019.pdf

EY. (2016). Poland imposes bank and insurance levy as of 1 February 2016. Retrieved from https://taxinsights.ey.com/ archive/archive-news/poland-imposes-bank-and-insurance-levy-as-of-1-february-2016.aspx

G20. (2009). G20 leaders statement: The Pittsburgh summit. Retrieved from http://www.g20.utoronto.ca/2009/ 2009communique0925.html

Gawehn, V. (2020). Banks and corporate income taxation: A review. Available at SSRN 3498843. https://doi.org/10.2 139/ssrn.3498843

Hanzlik, P., \& Teply, P. (2019). Key determinants of net interest margin of EU banks in the zero lower bound of interest rates. Retrieved from http://journal.fsv.cuni.cz/storage/1444_416_439_hanzlik_final_issue_5_2019.pdf

Haskamp, U. (2018). Spillovers of banking regulation: The effect of the German bank levy on the lending rates of regional banks and their local competitors. International Economics and Economic Policy, 15(2), 449-466. https://doi.org/10.1007/s10368-017-0404-4

Havrylchyk, O. (2012). Ensuring Stability and Efficiency of the Hungarian Financial Sector. OECD Economics Department Working Papers, No. 959, OECD Publishing, Paris, https://doi.org/10.1787/5k98rwrz1gvj-en.

Horvath, R. (2009). The determinants of the interest rate margins of Czech banks. Czech Journal of Economics and Finance (Finance a uver), 59(2), 128-136.

International Monetary Fund. (2010). A Fair and Substantial Contribution by the Financial Sector: Interim Report for the G-20. IMF. Retrieved from http://news.bbc.co.uk/2/shared/bsp/hi/pdfs/2010_04_20_imf_g20_interim_report.pdf

International Monetary Fund. (2010). A Fair and Substantial Contribution by the Financial Sector: Final Report for the G20. IMF. Retrieved from https://www.imf.org/external/np/g20/pdf/062710b.pdf

Jarno, K., \& Kolodziejczyk, H. (2018). Two Years of the Bank Tax in Poland-an Analysis of Effects. Bezpieczny Bank, (2 (71)), 86-95.

Kogler, M. (2019). On the incidence of bank levies: theory and evidence. International Tax and Public Finance, 26(4), 677-718. https://doi.org/10.1007/s10797-018-9526-z

Masiukiewicz, P., \& Dec, P. (2012). Special taxes in banking (No. 1231-2016-100814, pp. 61-68). https://doi.org/10.1 5208/pieb.2012.06

Ministry of Finance of Poland. (2020). Revenue, expenditure - execution. Retrieved from https://www.gov.pl/web/ finance/revenue-expenditure-execution 
Ministry of Finance of the Republic of Lithuania. (2020). Data on the Execution of the State budget and Municipal budgets. Retrieved from https://finmin.lrv.lt/en/actual-financial-data/data-on-the-execution-of-the-state-budget-andmunicipal-budgets

National Bank of Poland. (n.d.). Statistics. Retrieved from https://www.nbp.pl/homen.aspx?f=/en/statystyka/ statystyka.html

OECD. (2020). Composite leading indicator (CLI) (indicator). doi: 10.1787/4a174487-en. Retrieved from https://data.oecd.org/leadind/composite-leading-indicator-cli.htm

Perotti, E. C., \& Suarez, J. (2011). A Pigovian approach to liquidity regulation. Centre for Economic Policy Research. https://doi.org/10.2139/ssrn.1951799

Statistics Poland. (2020). Poland macroeconomic indicators. Retrieved from https://stat.gov.pl/en/poland-macroeconomicindicators/; https://doi.org/10.1787/c4e03b9c-en

Woolridge, J. M (2012). Introductory Econometrics: A Modern Approach. Thomson/South-Western, Cengage Learning.

\section{Authors' biographies}

Paulius Čeponis is a postgraduate student at ISM University of Management and Economics, also employed as an analyst in the banking sector. Paulius gained bachelor's degree in economics at ISM University of Management and Economics in 2020.

Marius Kušlys is a lecturer, doctoral student, and researcher at ISM University of Management and Economics. His research focuses on labour economics, migration. In 2020 Marius has participated in the research and development project "Industry 4.0: Addressing Challenges for Productivity, Employment and Inclusive growth". His teaching interests include macroeconomics, mathematics, and statistics. Marius gained a Master of Science degree in economics at ISM University of Management and Economics and since 2016 he is working at ISM.

Dr. Tadas Šarapovas is a Professor and Director of Economics and Data Analytics programme at ISM University of Management and Economics. Doctoral degree in Economics was awarded by Kaunas university of Technology in 2005 , Master of Science degree in International Business Management awarded in 2000. He has experience in running and managing small and medium-sized private enterprises, developing international trade and production outsourcing projects since 1999. His teaching area is Microeconomics, while his research interests are primarily focused on topics of microeconomics: business efficiency, business internationalization, and crisis diagnostics in a firm.

The article has been reviewed.

Received in July 2020; accepted in June 2021.

This article is an Open Access article distributed under the terms and conditions of the Creative Commons Attribution 4.0 (CC BY 4.0) License (http://creativecommons.org/licenses/by/4.0/). 